\title{
ВЫЗОВ ПОПУЛИЗМА В СОВРЕМЕННОЙ ЕВРОПЕ: УГРОЗА ИЛИ ИНСТРУМЕНТ ДЕМОКРАТИИ?
}

\begin{abstract}
Аннотация: Споры о природе политического популизма занимают существенное место в современной политической науке. Является он угрозой или «коррективой» демократии? C точки зрения автора, популизм одновре́менно служит как инструментом включения определённых групп электората в политическую жизнь, так и средством исключения из неё иных групп населения, которые объявлень «Другими». Такая амбивалентность популистского феномена усугубляется наглядными примерами пагубных последствий для либеральной демократии прихода популистов к власти.
\end{abstract}

Ключевые слова: популизм, начионализм, демократия, всеохватные партии.

Проблема правого популизма широко обсуждается в современном Европейском союзе. По-прежнему неясно, является он однозначной угрозой демократии, необходимой коррективой или же неотъемлемым элементом демократического процесса. От ответа на этот вопрос зависят экономическая и иммиграционная политика, политика в сфере безопасности, избирательные стратегии, академический и политический дискурс.

Прежде всего, необходимо определить, что есть популизм. Он может рассматриваться как стиль, стратегия или же «фрагментарная идеология» ${ }^{1}$. В данной статье мы исходим из того, что популизм - стратегия политической борьбы, которая подразумевает непосредственное обращение к «обычному народу» (т.н. «разреженный популизм»/thin populism, в терминологии исследователей Я. Ягерса и С. Валграве ${ }^{2}$ ) и противопоставление «добродетельного народа» «коррумпированной элите». Данная стратегия может комбинироваться с различными идеологиями (поэтому спорно утверждение, что популизм может считаться независимой идеологией сам по себе). В нашем случае популистская стратегия сочетается с нативизмом, что порождает второе противопоставление, уже горизонтальное: «мы» и «они/другие». Именно это сочетание и именуется обычно правым популизмом (то, что Я. Ягерс и С. Валграве назвали «плотным популизмом»/thick populism).

В условиях эрозии либеральной демократии, когда т.н. «традиционные» партии не представляют ряд электоральных групп (евроскептиков, традиционалистов и пр.), а их программы практически копируют друг друга, появляются партии, которые провозглашают себя истинным vox populi. Популизм не рождается из пустоты, для возникновения популистских пар-

(С Осколков Пётр Викторович - младший научный сотрудник Отдела исследований европейской интеграции ИЕ РАН. Aдрес: РФ, 125009, Москва, ул. Моховая, д. 11, стр. 3. Преподаватель кафедры региональных проблем мировой политики ФМР МГУ им. М.В. Ломоносова. Адрес: РФ, 119991, Москва, Ленинские горы, 1-51, ком. 602. E-mail: p.oskolkov@inno.mgimo.ru.

DOI: http://dx.doi.org/10.15211/vestnikieran2201810

${ }^{1}$ Мусихин Г.И. Популизм: структурная характеристика политики или «ущербная идеология»? Полития. №4, 2009. C. 40.

'Jagers J., Walgrave S. Populism as political communication style: An empirical study of political parties' discourse in Belgium. European Journal of Political Research. №46(3), 2007. P. 321. 
тий и движений необходима определённая плодородная почва. Одна из наиболее влиятельных теорий популизма была создана Э. Лакло, который заявил, что демократия невозможна без популистских элементов, и что каждый раз, когда правительство (или власть в широком её понимании) не прислушивается к требованиям народа, иначе говоря, когда в дискурсе образуется структурное противоречие, популистские элементы усиливаются, возникают идеологизированные комбинации, и наступает расцвет соответствующих политических акторов ${ }^{1}$. Другими словами, если определённые вызовы/запросы оказываются не представлены в программах «традиционных» партий, популисты могут заявить: «мы озвучиваем ваши мысли» (zeggen wat u denkt - лозунг бельгийской партии «Фламандский интерес»). В таком случае популизм начинает вести себя, как пьяный гость на вечеринке - не связанный нормами публичного поведения, говорящий всё, что у него в голове 2 .

Одна из главных проблем, связанных с правым популизмом, возникает в результате попыток определить, что есть «народ», интересы которого, как утверждают популисты, они представляют. «Народ» - очень гетерогенное понятие, и именно поэтому так называемые «партии для каждого» (catch-all parties, как их называет О. Кирххаймер) предельно размыли свои программы - чтобы они действительно подошли всем и каждому. В результате этого из программ были исключены некоторые действительно существенные пункты, и возникли группы, недовольные таким универсалистским подходом. Именно они - целевая аудитория популистов. Правые популисты на самом деле выражают только требования данных групп, хотя и представляют их как «весь народ». Таким образом они конструируют единый, гомогенный народ с единым набором требований. Чтобы его сконструировать, его необходимо както обозначить, ограничить, и обычно это делается путём негативной идентификации - указания на некоторые уязвимые группы как на разрушителей единства (стратегия «мы - не они»).

Один из наиболее известных примеров правопопулистской партии в современном Европейском союзе - бельгийский «Фламандский интерес» (партий федерального уровня в бельгийской политической системе нет; партийная система разделена по этнорегиональному принципу, поэтому в северной части страны действуют только фламандские партии, а в южной - только валлонские). В современной фламандской партийной системе большинство партий можно охарактеризовать как универсалистские (catch-all). В программах Христианских демократов и фламандцев (CDV), Другой социалистической партии (sp.a) и Открытых фламандских либералов и демократов (Open VLD) остались только небольшие акценты, указывающие на изначальную идеологию демохристиан, социалистов и либеральных демократов. В целом партийные программы основываются на общих для этих партий ценностях либеральной экономии, этического либертарианизма, мультикультурализма, европейской интеграции. «Фламандский интерес» - единственная партия, занимающая жёсткую позицию по иммиграционным, этическим и социальным вопросам, выступающая против европейского интеграционного проекта. Соответственно, у избирателей, которые разделяют подобные убеждения, не остаётся другого выбора, кроме как голосовать за «Интерес».

\footnotetext{
${ }^{1}$ Laclau E. On Populist Reason. London, 2007. Verso Publ. P. 87.

2 Arditi B. Politics on the Edges of Liberalism. Cambridge, 2012. Cambridge University Press. P. 78.
} 
Практически аналогичная картина наблюдается в Эстонии: три основных «традиционных» партии, ещё недавно считавшихся непримиримыми идеологическими противниками (Центристская партия, Социал-демократическая партия и «Союз Отечества и Res Publica»), составили новую правящую коалицию. Это предсказуемо вызвало разочарование традиционного электората данных партий и повысило популярность правопопулистской Эстонской консервативной народной партии, успешно эксплуатирующей имидж политического аутсайдера (однако на Рождество 2016 г. фракции ЭКНП в эстонском парламенте подарили квадратный метр паркета, что было призвано символизировать вхождение партии в истеблишмент - эстонское слово parketikõlblik, букв. «пригодный для паркета», можно перевести как «рукопожатный»).

В конце 2017 г. в Австрии было сформировано новое правительство: коалицию составили христианско-демократическая Австрийская народная партия, классическая «партия истеблишмента», и правопопулистская Австрийская партия свободы (FРÖ), на протяжении многих лет - enfant terrible австрийской политической сцены. При этом лидеру АНП С. Курцу пришлось во многом перенять риторику своих потенциальных коалиционных партнёров - в том числе, в вопросе о членстве Турции в ЕС, о нежелательности финансирования мусульманских детских садов (из-за того, что они препятствуют интеграции детей в австрийское общество), о создании лагерей для беженцев за пределами $\mathrm{EC}^{1}$.

Три примера, фламандский, эстонский и австрийский, демонстрируют также и проблему «других». Стремясь к укреплению национального единства фламандцев, идеологи «Фламандского интереса» указывают в качестве инородных групп, которые не должны иметь равные права в идеальном фламандском обществе, иммигрантов из мусульманских стран и валлонов (якобы эксплуатирующих фламандские средства и не желающих учить нидерландский язык). Для ЭКНП роль «других» исполняют всё те же мигранты из стран Ближнего Востока и Северной Африки (которых в стране практически нет, в отличие от Бельгии) и русскоязычное меньшинство. АПС является одной из наиболее радикально антииммигрантски настроенных западноевропейских партий.

Будучи порождением либеральной демократии, популизм (хотя и не сам по себе) оказался способен поставить под угрозу демократические ценности в тех странах, где пришёл к власти: в Венгрии и Польше. Вслед за Я.-В. Мюллером мы считаем необходимым отойти от изобретённого самими полулистами термина «нелиберальная демократия» ${ }^{2}$, но не из утилитарных соображений, а из теоретических: мы считаем необходимым придерживаться типологии политических режимов X. Линца, а у него демократия не знала оттенков и сортов, в отличие от следующего за ней авторитаризма. В настоящее время демократия может быть исключительно либеральной, если она сохраняет все необходимые типологические признаки демократического режима; в противном случае слово «демократия» - не более чем самоклеящийся ярлык, как в случае «народных» и «народно-демократических» республик. Посе-

\footnotetext{
${ }^{1}$ Швейцер В., Грибовский В. Австрия: консервативно-националистический альянс. Аналитическая записка ИЕ PAH №3(99), 2018. URL: http://instituteofeurope.ru/images/uploads/analitika/an99.pdf.

${ }^{2}$ Мюллер Я.-В. Что такое популизм? М., Изд. дом ВШЭ, 2018. С. 75.
}

Научно-аналитический вестник ИЕ РАН, 2018, №2 
му, если режим начинает именовать себя «нелиберальной демократией», это признак его постепенной трансформации в авторитарном направлении.

\section{Выводы}

Таким образом, главная положительная роль правопопулистских партий заключается в том, что они дают возможность избежать исключения из политической жизни тех групп населения, взгляды которых не отражают программы «традиционных» партий. С другой стороны, сами по себе правые популисты исключают в своих программах из «единого общества» некоторые группы, обозначаемые как «подрывающие единство», а также, в случае прихода к власти, зачастую ограничивают институты гражданского общества, - в любом случае мы имеем дело с политическим исключением отдельных групп граждан и явным ущербом демократическому процессу. Можно сказать, что правый популизм - элемент, присущий большинству демократий европейского типа, и ограничение деятельности соответствующих групп и партий негативно скажется на политических правах их традиционного электората; однако гражданское общество должно обозначить те «красные линии», за которыми начинается дискриминация популистских «других» и вред демократическим институтам, и которые правые партии не должны пересекать в своей деятельности.

\section{Список литературы}

Мусихин Г.И. Популизм: структурная характеристика политики или «ущербная идеология»? Полития, №4, 2009. С. 40-53.

Мюллер Я.-В. Что такое популизм? Изд. дом ВШЭ, М., 2018. 135 с.

Швейцер В., Грибовский В. Австрия: консервативно-националистический альянс. Аналитическая записка ИЕ РАН, №3(99), 2018. URL: http://instituteofeurope.ru/images/uploads/analiti ka/an99.pdf.

Arditi B. Politics on the Edges of Liberalism. CUP, Cambridge, 2012. 176 p.

Jagers J., Walgrave S. Populism as political communication style: An empirical study of political parties' discourse in Belgium. European Journal of Political Research, №46(3), 2007. P. 319345.

Laclau E. On Populist Reason. Verso, London, 2007. 252 p.

\section{References}

Arditi B. Politics on the Edges of Liberalism. CUP, Cambridge, 2012. 176 p.

Jagers J., Walgrave S. Populism as political communication style: An empirical study of political parties’ discourse in Belgium. European Journal of Political Research, № 46(3), 2007. P. 319345.

Laclau E. On Populist Reason. Verso, London, 2007. 252 p.

Muller J.-W. What is populism? [Chto takoye populizm?]. HSE Publ., Moscow, 2018. 135 p.

Musikhin G. Populism: structure feature of politics or thin ideology? [Populizm: strukturnaya kharakteristika politiki ili «ushcherbnaya ideologiya»?]. Politiya, №4, 2009.P. 40-53. 
Shveytser V., Gribovskiy V. Austria: conservative-nationalist alliance [Avstriya: konservativnonatsionalisticheskiy alyans]. Analytical report of Institute of Europe, №3(99), 2018. URL: http:// instituteofeurope.ru/images/uploads/analitika/an99.pdf.

\section{Populism challenge in contemporary Europe: Threat to or instrument of democracy?}

Author. Oskolkov P. - Junior Research Associate, Institute of Europe Russian Academy of Sciences. Address: 11-3, Mokhovaya str., Moscow, Russia, 125009. Lecturer, Department of Regional Issues of World Politics, School of World Politics, Lomonosov Moscow State University. Address: room 602, 1-51, Leninskiye gory, Moscow, Russia, 119991.E-mail: petroskolkov@yandex.ru.

Abstract. Discussions about the nature of political populism occupy an important place in contemporary political science. Is it a threat to democracy or a necessary corrective? The author thinks that populism is, at the same time, an instrument of inclusion of certain electoral groups in the political life and a means of exclusion of certain population groups that are proclaimed "the Other". Such ambivalence of populist phenomenon is strengthened by the examples that demonstrate ruinous consequences of a populist rule for liberal democracy.

Key words: populism, nationalism, democracy, catch-all parties.

DOI: http://dx.doi.org/10.15211/vestnikieran2201810 